\title{
Доцільність застосування циторедуктивної хірургії та гіпертермічної внутрішньочеревної хіміотерапії у хворих на рак яєчника. Дискусійні аспекти
}

\author{
О.П. Манжура ${ }^{1,2}$, Д.С. Осинський' ', І.В. Кухар' ${ }^{1}$, Є.В. Майстренко', С.П. Меренцев ${ }^{1}$, \\ В.Є. Міцкевич', Л.В. Гарасимчук, Ю.А. Чайка' ', А.В. Кондратенко' \\ 'Комунальне некомерційне підприємство «Київський міський клінічний онкологічний центр», Київ, Україна \\ ${ }^{2}$ Національний медичний університет імені О.О. Богомольця, Київ, Україна
}

\begin{abstract}
Анотація. Лікування розповсюдженого раку яєчника зазвичай включає циторедуктивну хірургію та системну хіміотерапію у поєднанні $з$ таргетною. Результати лікування на сьогодні $\epsilon$ невтішними, смертність становить 9,0 на 100 тис. жіночого населення незалежно від віку. Це спонукало до вивчення нових методів лікування, а саме гіпертермічної внутрішньочеревної хіміотерапії у поєднанні з циторедукцією. Ми провели аналіз літературних даних та різних досліджень, згідно з якими при застосуванні гіпертермічної внутрішньочеревної хіміотерапії у поєднанні з циторедукцією безрецедивна виживаність хворих на розповсюджений рак яєчника підвищується на 3,5 міс, а загальна виживаність - на 11,8 міс.
\end{abstract}

Ключові слова: рак яєчника, гіпертермічна внутрішьочеревна хіміотерапія, циторедуктивна хірургія, безрецедивна та загальна виживаність.

\section{Вступ}

Рак яєчника (РЯ) займає 7-ме місце серед усіх злоякісних захворювань у жінок в світі. За попередній рік, за даними Всесвітньої організації охорони здоров'я та European Cancer Information System, захворюваність на РЯ у світі становила 6,6 на 100 тис. жіночого населення (313956 вперше виявлених випадків). В Україні РЯ займає 6-темісце —-18,6 на 100 тис. жіночого населення (3545 випадків). 3агалом РЯ є великою проблемою, оскільки приблизно у 65-70\% випадках виявляється в розповсюджених стадіях (III-IV) [1-4].

Згідно $з$ міжнародними протоколами застосовують наступні методи лікування РЯ: хіміотерапевтичне, хірургічне, а також використовують таргетну терапію та інколи опромінення за Stripтехнікою. Однак, незважаючи на різноманітні схеми хіміотерапії та застосування таргетної терапії, хірургічний компонент в обсязі оптимальної циторедукції (cytoreductive surgery - CRS) $\epsilon$ основним. I навіть у цьому випадку результати загальної виживаності та смертності $\epsilon$ невтішними. Смертність від РЯ, незалежно від стадії, у світі займає 8-ме місце серед онкологічних захворювань і становить 2,8 на 100 тис. серед всього населення (20 7252 випадків), в Україні —9,0 на 100 тис. жіночого населення (1713 випадків) незалежно від віку [1-3, 5, 6].

Саме тому в останні десятиріччя активно дискутується питання щодо поєднання CRS та гіпертермічної внутрішньочеревної хіміотерапії (hyperthermic intraperitoneal chemotherapy HIPEC) із застосуванням хіміопрепарату (цисплатин).

F. Хіе та співавтори (2020) стверджують, що якщо застосовувати цисплатин у мінімальній дозі 75 мг/м² площі поверхні тіла, то знижується ймовірність виникнення нефротоксичності при тривалості НІРЕС протягом 1-2 год. При застосуванні цисплатину у дозі 100 мг/м² протягом 1 год підвищується нефротоксичність, що призводить до загрози для життя пацієнтки, адже гіпертермія збільшує швидкість поглинання цисплатину на 16,3\% [7].

На відмінну від попередніх авторів, L.M. Chambers та співавтори (2020) описують застосування цисплатину в дозі $100 \mathrm{Mr} / \mathrm{M}^{2}$ окремо або в комбінації з паклітакселом 135-175 мг/м² із загальним часом перфузії 90 хв. Вони стверджують, що при застосуванні таких схем під час НIPЕС ризик виникнення нефротоксичності мінімальний. Однак під час процедури необхідна пильна увага до контролю температури тіла та глікемії, оскільки можуть виникати електролітні порушення, включаючи гіперглікемію, молочнокислий ацидоз та гіпокаліємію. Постійний моніторинг стану пацієнтів та попередження порушень, що виникають під час HIPEC, надзвичайно важливі для зниження ризику розвитку ускладнень та смертності пацієнтів [8].

Авторипублікації «Hyperthermic intraperitoneal chemotherapy (HIPEC) for ovarian cancer recurrence: systematic review and metaanalysis» стверджують, що у жінок з рецидивуючим РЯ застосування HIPEC разом $з$ циторедукційною хірургією та хіміотерапією значно покращує загальну однорічну виживаність (overall survival -OS) порівняно з протоколами без HIPEC [9].

У публікації J. Spiliotis та співавторів (2021) зазначено, що HIPEC $\epsilon$ альтернативою у жінок із запущеним РЯ. $\epsilon$ труднощі 3 включенням НIPEC у стандарт медичної допомоги через різницю та нестандартизацію різних досліджень та протоколів. Тому вони сподіваються, що подальші дослідження в цьому напрямку дадуть більше інформації стосовно застосування НIPEC при первинному та рецидивуючому РЯ [10].

Аналізуючи дані ретроспективного дослідження щодо НIPEC за участю 112 пацієнток із РЯ, яким проведено циторедуктивну хірургію та НІРЕС в період 2005-2019 рр., доведено, що результати виживаності однакові у хворих з та без НІРЕС. Тому автори наполягають на проведенні рандомізованих досліджень [11].

M. Friedrich та співавтори (2020) зробили оцінку побічних ефектів HIPEC при РЯ і дійшли висновку, що при РЯ може знадобитися багаторазове хірургічне втручання для макроскопічного знищення пухлинної тканини в комбінації з НIPEC, що в поєднанні покращує виживаність пацієнток з перитонеальним канцероматозом [12].

S.N. Koole та співавтори (2021) у публікації «Health-related quality of life after interval cytoreductive surgery with or without hyperthermic intraperitoneal chemotherapy (HIPEC) in patients with stage III ovarian cancer» зазначають, що додавання HIPEC до інтервальної циторедукційної хірургії (CRS) позитивно впливає на якість життя (Health-Related Quality of Life - HRQoL) паці$\epsilon$ тток із РЯ. Результати щодо покращення HRQoL разом із поліпшенням безрецидивного періоду (recurrence-free survival —RFS) та OS підтримують життєздатність HIPEC як важливого варіанту лікування у цій популяції пацієнток [13].

У багатоцентровому відкритому рандомізованому дослідженні фази III вивчали ефективність поєднання НIPEC з інтервальною CRS у пацієнток з РЯ III стадії, які отримували неоад'ювантну хіміотерапію. У дослідженні взяли участь 245 пацієнток, середній період спостереження $-4,7$ року. Дизайн дослідження наступ- 
ний: пацієнтки отримували 3 курси неоад'ювантної хіміотерапії (карбоплатин+паклітаксел у стандартних дозах) з наступним етапом інтервальної CRS з або без проведення HIPEC з цисплатином (100 мг/M²). Рандомізацію проводили під час операції у випадках повної або оптимальної циторедукції. Після операції проводили 3 цикли ад'ювантної хіміотерапії з карбоплатином та паклітакселом. Первинною метою була оцінка RFS, вторинною - оцінка загальної виживаності і профілю побічних ефектів. Під час лікування рецидив захворювання відмічений у 110 із 123 пацієнток (89\%), які отримали тільки CRS (група хірургічного втручення), та у 99 із 122 (81\%) пацієнток, які отримували CRS+HIPEC (група хірургічного втручення+НIPEC) (коефіцієнт ризику рецидиву захворювання або смерті 0,66; 95\% довірчий інтервал (ДІ) 0,50-0,87; p=0,003). RFS становила 10,7 міс у групі CRS та 14,2 міс у групі CRS+HIPEC. Померли 76 хворих (62\%) хірургічної групи та 61 пацієнтка (50\%) у групі хірургічного втручання+НIPEC (коефіцієнт ризику 0,67; 95\% ДІ 0,48-0,94; p=0,02). Середня загальна виживаність становила 33,9 міс в групі хірургічного втручання та 45,7 міс -у групі хірургічного втручання+НIPEC. Частка пацієнток, у яких виявлено побічні ефекти 3-го або 4-го ступеня, була подібною у двох групах (25 та $27 \%$ у групі хірургічного втручання та хірургічного втручання+НІРЕС відповідно; $p=0,76)$.

Таким чином, додавання HIPEC до інтервальної CRS при лікуванні пацієнток з епітеліальним РЯ III стадії зумовило більш тривалу безрецидивну виживаність (на 3,5 міс) та загальну виживаність (на 11,8 міс) та не призвело до розвитку більш високого рівня побічних ефектів [14].

Як показано в таблиці, додавання HIPEC до CRS збільшує RFS на 10-11,8 міс, 3-річну виживаність —на 7,6-15,5\%, тоді як 5-річна виживаність підвищується на 10,5-14,5\% [15-17]. Наразі триває випробування OVHIPEC-2, яке розпочалося у січні 2020 р., а первинні аналізи очікуються в 2026 р. [18].

Таблиця Порівняльна характеристика результатів лікування методом CRS та HIPEC на основі різних літературних джерел [15-17]

\begin{tabular}{lccc}
\hline $\begin{array}{c}\text { Метод } \\
\text { лікування }\end{array}$ & $\begin{array}{c}\text { Тривалість } \\
\text { RFS, міс }\end{array}$ & $\begin{array}{c}\text { 3-річна } \\
\text { виживаність, } \\
\text { \% хворих }\end{array}$ & $\begin{array}{c}\text { 5-річна } \\
\text { виживаність, } \\
\text { \% хворих }\end{array}$ \\
\hline CRS & $29,2-33,9$ & $31,1-57,4$ & $42,3-53,9$ \\
\hline CRS+HIPEC & $19,2-45,7$ & $46,6-65,0$ & $52,8-68,4$ \\
\hline
\end{tabular}

\section{Клінічний випадок}

Хвора В., 1963 р.н. у серпні 2018 р. звернулася за медичною допомогою у комунальне некомерційне підприємство «Київський міський клінічний онкологічний центр», гінекологічне відділення. Скарги на постійний ниючий біль помірної інтенсивності в ділянці гіпогастрія, збільшення живота в об'ємі, зменшення маси тіла на 6-7 кг за 3 міс, задишку при ходьбі, запаморочення, загальну слабкість.

На момент госпіталізації об'єктивний стан відносно задовільний. Індекс маси тіла $-28 \mathrm{kr} / \mathrm{M}^{2}$.

При гінекологічному огляді зовнішні статеві органи розвинуті правильно, патології не виявлено, шийка матки епітелізована.

Цитологічне дослідження від 08.07.2018р. № 25683/18: «Шийка матки: клітини плоского епітелію поверхневого типу. Цервікальний канал: групи клітин залозистого епітелію, ознаки гіперплазії».

При пальпації per vaginum: у малому тазі в єдиному пухлинному конгломераті визначається матка з додатками, збільшені до 10х10 см у діаметрі, щільної структури, бугристість у задньому склепінні.

Комп'ютерна томографія трьох зон (органів грудної порожнини, органів малого таза, органів черевної порожнини) з внутрішньовенним контрастуванням від 12.07.2018 р.: «Двобічний рак яєчника (101×95×101мм) з метастатичними пошкодженнями тазової очеревини. Асцит».

Онкомаркери від 12.07.2018 р.: СА-125 -588,9 МЕ/мл, НЕ 4 2065 пмоль/л.
02.08.2018 р. виконана діагностична лапароскопія, біопсія яєчників. Патогістологічний висновок від 10.08.2018 р. № 5964954: «Серозна карцинома обох яєчників high grade».

Проведено 3 курси неоад'ювантної поліхіміотерапії за схемою: паклітаксел 280 мг, карбоплатин 450 мг.

Комп'ютерна томографія трьох зон (органів грудної порожнини, органів малого таза, органів черевної порожнини) з внутрішньовенним контрастуванням від 27.10.2018 р.: «Зменшення пухлин яєчників до 65×50×65мм, канцероматоз великого сальника значно зменшився».

Онкомаркери від 29.10.2018 р.: СА-125 -50 ME/мл, НЕ 4 -1460 пмоль/л.

Операція 08.11.2018 р.: оптимальна циторедукція R0, пангістеректомія II типу з оментектомією, НІРЕС (цисплатин 100 мг/м²).

Патогістологічне дослідження від 15.11.2018 р. № 8492143/18: «Серозна карцинома обох яєчників G3, лікувальний патоморфоз ІІ ст. Сальник: повнокровний. Маткові труби: повнокровні. Вузлова лейоміома, поліп ендометрія кістозно-атрофічного типу. Цервікальний канал: наботові кісти. Шийка матки: паракератоз багатошарового плоского епітелію».

Надалі пацієнтка отримала 4 курси ад'ювантної поліхіміотерапії за такою схемою: паклітаксел $280 \mathrm{mг} / \mathrm{M}^{2}$, цисплатин 100 мг/м². Лікування закінчила у квітні 2019 р.

Плановий огляд 03.03.2019 р. після оперативного лікування: даних щодо рецидиву не виявлено, культя піхви сформована, епітелізована, інфільтратів у малому тазі не виявлено.

При повторному огляді від 01.07.2019 р. при пальпації per vaginum: культя піхви сформована, епітелізована, інфільтратів у малому тазі не виявлено.

Комп'ютерна томографія трьох зон від 26.06.2019 р.: «Даних щодо локального рецидиву і вісцеральних метастазів не виявлено. Рубцеві зміни у правій молочній залозі та правій пахвовій ділянці».

Онкомаркери від 05.06.2019 р.: СА-125 —9,0 ME/мл, НE 4 43,7 пмоль/л. При наступному огляді в динаміці від 11.03.2020 р.: СА- $125-10 \mathrm{ME} / \mathrm{M}$.

Ультразвукове дослідження органів малого таза й органів черевної порожнини: «Даних щодо рецидиву не виявлено».

Огляд від 29.03.2021 р.: СА-125 - 11 МЕ/мл, НЕ 4 -81 пмоль/л.

Комп'ютерна томографія трьох зон від 28.04.2021 р.: «Даних щодо рецидиву та вісцеральних метастазів не виявлено».

\section{Висновок}

Метод НІРЕС, застосований у хворих на розповсюджений РЯ, демонструє кращі показники виживаності та безрецидивного періоду, але потребує подальшого вивчення.

\section{Список використаної літератури/References:}

1. ecis.jrc.ec.europa.eu/.

2. www.ncru.inf.ua/publications/index.htm.

3. World Health Organization (2020) Global Health Estimates 2020: Deaths by Cause, Age, Sex, by Country and by Region, 2000-2019 (who.int/data/gho/data/themes/mortality-andglobal-health-estimates/ghe-leading-causes-of-death).

4. Committeeon Gynecologic Practice, Society of Gynecologic Oncology (2017) Committee Opinion No. 716: Ther ole of the obstetrician-gynecologist in thee arlyde tection of epithelial ovarian cancer in women ataverage risk. American College of Obstetricians and Gynecologists. Obstet. Gynecol., 130(3): 146-149.

5. Ferlay J., Colombet M., Soerjomataram I. et al. (2018) Global and Regional Estimates of the Incidence and Mortality for 38 Cancers: GLOBOCAN 2018. International Agency for Research on Cancer/World Health Organization.

6. Ferlay J., Colombet M., Soerjomataram I. et al. (2019) Estimating the global cancer incidence and mortality in 2018: GLOBOCAN sources and methods Int. J. Cancer, 144: 1941-1953.

7. Xie F., Van Bocxlaer J., Colin P. et al. (2020) PKPD Modeling and Dosing Considerations in Advanced Ovarian Cancer Patients Treated with Cisplatin-Based Intraoperative Intraperitoneal Chemotherapy. The AAPS J., 22(5): 1-12.

8. Chambers L.M., Costales A.B., Crean-Tate K. et al. (2020) A guide to establishing a hyperthermic intraperitoneal chemotherapy program in gynecologic oncology. Gynecol. Oncol., 158(3): 794-802. doi: 10.1016/j.ygyno.2020.06.487. 
9. Cianci S., Riemma G., Ronsini C. et al. (2020) Hyperthermic intraperitoneal chemotherapy (HIPEC) for ovarian cancer recurrence: systematic review and meta-analysis. gs.amegroups. com/article/view/44562/html.

10. Spiliotis J., lavazzo Ch., Fotiou A. et al. (2021) Upfront or intermediate treatment of advanced ovarian cancer patients with cytoreduction plus HIPEC: Results of a retrospective study. J. Surg. Oncol., 123(2): 630-637. doi: 10.1002/jso.26280.

11. Mishra M., Singh N., Ghatage P. (2021) Past, Present, and Future of Hyperthermic Intraperitoneal Chemotherapy (HIPEC) in Ovarian Cancer. Cureus, 13(6): e15563. doi:10.7759/cureus.15563

12. Friedrich M., Zinn W., Kolnsberg L. et al. (2020) Hyperthermic Intraperitoneal Chemotherapy (HIPEC) for Ovarian Cancer: Evaluation of Side Effects in a Single Institution Cohort. Anticancer Res., 40(3): 1481-1486. doi: 10.21873/anticanres. 14092.

13. Koole S.N., Kieffer J.M., Sikorska K. et al. (2021) Health-related quality of life after interval cytoreductive surgery with or without hyperthermic intraperitoneal chemotherapy (HIPEC) in patients with stage III ovarian cancer. Eur. J. Surg. Oncol., 47(1): 101-107.

14. van Driel W.J., Koole S.N., Sikorska K. et al. (2018) Hyperthermic intraperitoneal chemotherapy in ovarian cancer. New Engl. J. Med., 378(3): 230-240.

15. Lustosa R.J.C.,BatistaTh.P., Carneiro V.C.G. etal. (2020) Quality of life in a phase2 2trial of short-course hyperthermic intraperitoneal chemotherapy (HIPEC) at interval debulking surgery for high tumor burden ovarian cancer. Rev. Col. Bras. Cir., 47: e20202534. doi: 10.1590/0100-6991e-20202534.

16. Lei Z., Wang Y., Wang J. et al. (2020) Evaluation of cytoreductive surgery with or without hyperthermic intraperitoneal chemotherapy for stage Ill epithelial ovarian cancer. JAMA Netw Open, 3(8): e2013940.

17. Helm C.W., Richard S.D., Pan J. et al. (2010) Hyperthermic intraperitoneal chemotherapy in ovarian cancer: first report of the HYPER-0 registry. Int. J. Gynecol. Cancer, 20(1):61-69. doi: 10.1111//GC.0b013e3181c50cde.

18. clinicaltrials.gov/ct2/show/NCT03772028.

\section{Відомості про авторів:}

Манжура Олена Петрівна — кандидат медичних наук, доцент кафедри онкології Національного медичного університету імені 0.0. Богомольця, завідувач відділення онкогінекології КПН «Київський міський клінічний онкологічний центр», Київ, Україна. Головний консультант $з$ онкогінекології Д03 м. Київ.

Осинський Дмитро Сергійович - доктор медичних наук, лікар хірург-онколог вищої категорії, лікар з організації і управління охороною здоров'я вищої категорії, головний спеціаліст з онкології Д03 м. Київ, заступник директора з амбулаторно-поліклінічної роботи КПН «Київський міський клінічний онкологічний центр», Київ, Україна.

Кухар Ігор Володимирович — лікар хірург-онколог, мамолог КПН «Київський міський клінічний онкологічний центр», Клініка «Здорова сім'я», Київ, Україна.

Майстренко Євгеній Віталійович — лікар хірург, онколог-гінеколог КПН «Київський міський клінічний онкологічний центр», Київ, Україна.

Меренцев Сергій Павлович — лікар хірург-онколог КПН «Київський міський клінічний онкологічний центр», Київ, Україна.

Міцкевич Валентина Євгенівна — кандидат медичних наук, лікар онколог-гінеколог КПН «Київський міський клінічний онкологічний центр», Київ, Україна.

Гарасимчук Лілія Володимирівна — лікар акушер-гінеколог, Київ, Україна.

Чайка Юлія Анатоліївна — лікар онколог-гінеколог КПН «Київський міський клінічний онкологічний центр», Київ, Україна.

Кондратенко Андрій Віталійович — виконувач обов'язків директора КПН «Київський міський клінічний онкологічний центр», Київ, Україна.

Адреса для кореспонденції:

Манжура Олена Петрівна

03115, Київ, вул. Верховинна, 69

E-mail:manzhuraelena@gmail.com

\section{Expediency of cytoreductive surgery and hyperthermic intraperitoneal chemotherapy in patients with ovarian cancer. Discussion aspects}

O.P. Manzhura', ${ }^{1}$, D.S. Osynsky', I.V. Kuhar', Ye.V. Maistrenko', S.P. Merentsev' ${ }^{1}$, V.Ye. Mickiewicz' ${ }^{1}$ L.V. Garasymchuk, Yu.A. Chaika' ${ }^{1}$ A.V. Kondratenko'

'KNP «Kyiv City Clinical Oncology Center», Kyiv, Ukraine

${ }^{2}$ O.O. Bogomolets National Medical University, Kyiv, Ukraine

Abstract. Treatment for advanced ovarian cancer usually involves cytoreductive surgery and systemic chemotherapy in combination with targeted. The results of treatment are still disappointing and rate of mortality 9.0 per 100,000 female population, regardless of age. This led to the study of new treatments, namely, hyperthermic intra-abdominal chemotherapy in combination with cytoreductive. We have analyzed various studies and studies based on which the use of HIPEC combination with cytoreduction recurrence-free survival for patients with advanced ovarian cancer by 3.5 months and the overall survival rate by 11.8 months.

Key words: ovarian cancer, hyperthermic intra-abdominal chemotherapy, cytoreductive surgery, relapse-free and overall survival.

\section{Information about the authors:}

Manzhura Olena P. - Candidate of Medical Sciences, Associate Professor of the Department of Oncogynecology of KNP «Kyiv City Clinical Oncology Center», Associate Professor of the Department of Oncology of the 0.0 . Bogomolets National Medical University, Kyiv, Ukraine. Chief Consultant in Oncogynecology of the Kyiv Healthcare Department.

Osynsky Dmytro S. — Doctor of Medical Sciences, Surgeon-Oncologist of the highest category, Doctor of Organization and Management of the highest category of health care, Chief Specialist of Kyiv Healthcare Department, Deputy Director of Outpatient Clinic of KNP «Kyiv City Clinical Oncology Center», Kyiv, Ukraine.

Kuhar Ihor V. — Surgeon-Oncologist, Mammologist of KNP «Kyiv City Clinical Oncology Center», Clinic «Healthy Family», Kyiv, Ukraine.

Maistrenko Yevheniy V. — Surgeon, Oncologist-Gynecologist of KNP «Kyiv City Clinical Oncology Centers, Kyiv, Ukraine.

Merentsev Serhiy P. — Oncologist Surgeon of KNP «Kyiv City Clinical Oncology Center», Kyiv, Ukraine.

Mickiewicz Valentyna Ye. — Candidate of Medical Sciences, Oncologist-Gynecologist of KNP «Kyiv City Clinical Oncology Center», Kyiv, Ukraine.

Garasymchuk Lilia V. — Obstetrician-Gynecologist, Kyiv, Ukraine.

Chaika Yuliya A. — Oncologist-Gynecologist of KNP «Kyiv City Clinical Oncology Center», Kyiv, Ukraine.

Kondratenko Andriy V. - Acting Director of KNP «Kyiv City Clinical Oncology Center», Kyiv, Ukraine.

Address for correspondence:

Olena Manzhura

03115, Kyiv, Verkhovynna str., 69

E-mail:manzhuraelena@gmail.com 